УДК 340.121

DOI 10.18413/2712-746X-2020-45-4-775-780

\title{
Концепция христианского государства Н.А. Бердяева
}

\author{
Сафронов Н.А. \\ Белгородский областной суд \\ 308000, Россия, г. Белгород, ул. Гражданский проспект, д. 49 \\ E-mail: nik.safronov.1992@mail.ru
}

\begin{abstract}
Аннотация. Статья посвящена исследованию взглядов крупнейшего российского политического и религиозного философа Н.А. Бердяева (1874-1948) на государственно-церковные отношения в истории России. Бердяевым предложена интересная концепция, согласно которой история человечества не знает реально существовавших христианских государств. Символически государства могли называться христианскими, но по сути таковыми не являлись. Признаками формально христианских государств выступали вероисповедное господство, клерикализация, иерократическое подчинение, отсутствие свободы вероисповедания. При этом вероисповедным может быть и светское государство, подчиненное сатанократической религии. Бердяев полагал, что задачей Церкви должно быть не стремление к вероисповедному господству, а христианизация общества. Отсутствие свободы вероисповедания, привилегированное положение какой-либо религии приводит к зависимости Церкви от государства и формированию системы государственной церковности.
\end{abstract}

Ключевые слова: государство, церковь, христианское государство, государственно-церковные отношения, Н.А. Бердяев, концепция, доктрина.

Для цитирования: Сафронов Н.А. 2020. Концепция христианского государства Н.А. Бердяева. NOMOTHETIKA: Философия. Социология. Право. 45 (4): 775-780. DOI 10.18413/2712-746X-202045-4-775-780

\section{The concept of the Christian state by N.A. Berdyaev}

\author{
Nikita A. Safronov \\ Belgorod regional court \\ 49 Grazhdansky Prospekt, Belgorod, 308000, Russia \\ E-mail: nik.safronov.1992@mail.ru
}

\begin{abstract}
The article is devoted to the study of the views of the largest Russian political and religious philosopher Nikolai Alexandrovich Berdyaev (1984-1948) on state-Church relations in the history of Russia. N. A. Berdyaev proposed an interesting concept, according to which the history of mankind does not know any real Christian States. Symbolically, States could be called Christian, but in fact they were not. Signs of formally Christian States were religious domination, clericalization, and lack of religious freedom. At the same time, a secular state subordinate to the religion of Satan can also be religious. Berdyaev believed that the task of the Church should not be to strive for religious domination, but to Christianize society. The lack of freedom of religion, the privileged position of any religion leads to the dependence of the Church on the state and the formation of a system of state ecclesiasticism. The spiritual impact of the Church and the Christian faith on the cells of society is important for the maximum and real Christianization of society.

Key words: state, Church, Christian state, state-Church relations, N. A. Berdyaev, concept, doctrine.

For citation: Safronov N. A. 2020. The concept of the Christian state by N. A. Berdyaev. NOMOTHETIKA: Philosophy. Sociology. Right. 45 (4): 775-780 (in Russian). DOI 10.18413/2712746X-2020-45-4-775-780
\end{abstract}




\section{Введение}

Проблему взаимоотношения церкви и государства следует признать вечной. Нельзя не согласиться с Н.А. Бердяевым, что «вопрос об отношении церкви и государства - вековечный вопрос христианского сознания и вместе с тем злободневный вопрос». Не теряет он своей злободневности и сегодня. Российская Федерация - светское государство, в котором, однако, подавляющее большинство позиционирует себя православным, что не может не ставить многочисленных вопросов о взаимодействии государства с самой крупной структурированной религиозной организацией в стране - Русской Православной Церковью. В этой связи особый интерес представляет обращение к отечественной политикоправовой доктрине, исследовавшей данную тему в аспекте развития. При этом особое значение имеют работы христианских политических мыслителей начала XX века, когда кардинальным образом менялась модель взаимоотношений государства и церкви. К их числу следует отнести М.Н. Булгакова, Н.А. Бердяева, И.А. Ильина, П.И. Новгородцева, С.Л. Франка и др., ставших живыми свидетелями крушения традиционного для постпетровской России цезаропапизма и в своих трудах проанализировавших данный процесс.

Интерес к их творчеству в отечественной историко-правовой историографии обозначился в конце 90-х - начале 2000-х гг. Так, в работах Т.Б. Сазоновой [1998] С.В. Акопова [2001], А.Э. Чернокова [2002], А.Л. Яхиной [2007], М.А. Ментюковой [2009] И.Р. Фоминой [2010] Е.А. Фроловой [2013], Д.В. Алонцевой [2013] на диссертационном уровне рассматриваются государственно-правовые воззрения русских религиозных мыслителей, исследовавших тему государственно-конфессиональных отношений. Однако вне исследовательского интереса осталось имя крупнейшего российского политического и религиозного философа Николая Александровича Бердяева (1874-1948 гг.) - автора целой серии работ, посвященных проблеме государственно-церковных отношений [1907, 1910, $1911,1927,1946]$.

\section{Н.А. Бердяев об истории государственно-церковных отношений}

Николай Александрович Бердяев был одним из самых оригинальных русских религиозных мыслителей начала XX века, автором концепции свободы, талантливым политическим писателем, семь раз номинированным на Нобелевскую премию по литературе. Значительное место в его творчестве занимала проблема взаимоотношений церкви и государства. Н.А. Бердяев полагал, что отношения государства к церкви и церкви к государству не должны быть статичными. Они определяются как общемировыми, так и национальными политическими процессами. Так, христианские церкви на Западе (католическая и протестантские), по его мнению, научились жить при любой форме государства. К началу XX в. цезаропапистской модели государственно-церковных отношений в Европе уже не существовало.

Иная ситуация складывалась на православном Востоке. Восприняв византийские традиции, в России «православная церковь привыкла существовать в православном царстве под православным царем» [Бердяев, 1927, с. 280]. Кардинальная перестройка церковно-государственных отношений, ставшая следствием революционных событий, имела не только в целом общественно-политические, но и внутрицерковные причины. Н.А. Бердяев полагал, что синодальный период церковной истории Российской Империи привел к порабощению церкви государством. «Система государственной церковности, государственное православие казенного образца порождало лицемерие и ложь, было приспособлением церкви для кесаревых целей» [Бердяев, 1927, с. 282].

В католических станах Запада отношения государства и церкви были сложными и характеризовались борьбой, которая осуществлялась в разных формах, однако, по мнению Бердяева, это не мешало христианизации общества. В восточно-христианских странах, начиная с императора Константина, государственно-церковные отношения развивались 
по-другому пути: через создание православной империи (византийское и русское царства), где церковь попала в зависимость от государства, а государство получило христианские атрибутивы, но христианским не стало.

\section{Катехоническая концепция государства}

Важнейшей проблемой, волновавшей Н.А. Бердяева и многих его современников, была проблема формирования христианского государства и христианизация власти.

В восточно-христианской традиции отношение к государству базируется на катехонической концепции. «Катехон» (удерживающий) - богословское понятие, под которым понимается властный субъект (государство), наделенный миссией препятствовать торжеству греха и Антихриста (злой сущности). Христианская доктрина «удерживающего» была сформулирована во II послании апостола Павла к христианской общине Фессалоник.

Второе послание апостола лежало в основе христианской эсхатологии, определяло ее фундаментальные категории - «антихрист», «катехон» (удерживающий), «апостасия» (отступление).

Катехоническая концепция представлена в трудах Иоанна Златоуста, Евсевия Кесарийского, Ефрема Сирина, Козьмы Индикоплова и др. Политическое оформление катехонической концепции базировалось на византийской традиции, которая отождествляла «удерживающего» с личностью императора Римской (Византийской) империи - автократом (самодержцем).

Однако после церковного раскола - «Великой схимы» 1054 г., следствием которой стало разделение христианской церкви на католическую и православную, единство христианского понимания катехона как «удерживающего царства» теряется, получая ряд толкований. Согласно первому - под «удерживающим» понимается Римское государство, удерживающее общество от безвластия и разгула греха. Согласно второму - под «катехоном» понимается благодать Святого Духа, которую человечество теряет из-за потери любви, и, наконец, согласно третьему толкованию катехон - это проповедь Евангелия, предшествующая концу времен.

Трактовка катехона (удерживающего от зла) в христианской традиции также связана с идеей хилиазма - тысячелетнего царствования Христа, до конца времен, когда «змий» будет скован, но еще не побежден. Теория хилиазма (милленариизма) в христианской доктрине имеет целый ряд трактовок (премилленаризм, постмилленаризм и амилленаризм).

В православной традиции распространена амилленаризская трактовка, в соответствии с которой тысячелетнее царство понимается аллегорически. В православных политических трактовках идея хилиазма связывается с понятием империи и царствованием христианских императоров (православных царей). Согласно византийскому обоснованию автократии император (самодержец) - это «катехон», удерживающий мир от зла, безвластия и воцарения антихриста. В русской политической доктрине как преемнице византийской самодержавие (от греч. «автократия») означало фактический суверенитет, то есть власть, не нуждающуюся в дополнительной легитимации. Теория «Москва - Третий Рим» (1523-1524 г.), сформулированная в послании игумена псковского монастыря Филофея великому князю Василию Ивановичу, выводила преемственность катехонической власти.

Ряд представителей российской консервативной политической доктрины (Л.А. Тихомирова, П.Е. Казанского, Н.А. Захарова, В.Д. Каткова, И.А. Ильина, Е.Н. Трубецкого) были сторонниками катехонической концепции.

\section{Н.А. Бердяев о христианизации государства}

Н.А. Бердяев такого подхода не разделял. По его мнению, миропомазание и освящение монархической власти церковью базируется не на христианских источниках, а на 
исторической традиции. «Государство склонилось перед христианством, но никогда на протяжении всего Константиновского периода не христианизировалось реально, не стало вполне и до конца христианским по своей природе, по своему принципу» [Бердяев, 1927, c. 284]. Религиозное освящение власти присуще не только христианству, но и язычеству.

Н.А. Бердяев доказывал: «Государство освящается церковью, оно в идее перестает быть царством зверя, но церковь искажается государством, порождается государственная церковность» [Бердяев, 1927]. В евангельских текстах, утверждал он, говорится о наличии различных порядков: бытия Божьего и бытия кесарева, смешение которых опасно для обоих начал. Главное отличие христианского государства виделось в спасении человеческих душ для жизни вечной, однако для реализации религиозных целей государство использует проверенный аппарат принуждения как одно из средств спасения, что, с одной стороны, приводит к государственному принуждению в духовной жизни, а с другой превращает церковь в средство реализации государственных целей.

С.Н. Бердяев пришел к выводу, что реально существующих христианских (теократических) государств мировая история не знает. Государство может быть лишь формально (символически) христианским. Признаками формально теократических государств выступало вероисповедное господство, клерикализация, иерократическое подчинение, отсутствие свободы вероисповедания. «Христианство не проникало достаточно реально в жизнь, не осуществлялось в полноте жизни, а лишь условно символизировалось. Эта символизация совершалась через сакраментальные акты церкви в отношении к государству, помазание царя на царство, церковное освящение государственной власти и ее актов» [Бердяев, 1927, с. 285].

Главной причиной, препятствующей христианизации общества, Н.А. Бердяев считал отсутствие вероисповедной свободы. Он полагал, что общественная идея христианского государства строится без ее учета. Христианизация государства всегда осуществлялась принудительно. Однако «онтологически реально в жизни лишь то, на что дает свое активное согласие человеческая свобода». Без участия свободной воли изменение невозможно. Вот почему свобода религиозной совести есть необходимое условие реальной христианизации и реального преображения жизни. Задачей церкви Бердяев считал внутреннюю христианизацию общества, а не «создание православной государственной власти» [Бердяев, 1927, с. 297].

\section{Н.А. Бердяев об отношении церкви к государству}

Вопрос отношения христианства к государству Н.А. Бердяев считал важным. Он предпринял попытку сформулировать принципы, на которых должно строиться отношение церкви к государству. Значение государственной власти, по его мнению, христианством не отрицается. «Власть государственная призвана предотвращать хаос и распадение и способствовать упорядочению и организации жизни, должна применять и принуждение для целей добра» [Бердяев, 1927, с. 300]. Однако церковь не должна абсолютизировать государственную власть и форму ее организации.

Напротив, христианство, обосновавшее свободу воли человека, должно ограничивать проявление государственного насилия. «Христианство, - писал он, - не считает никакой формы государственной власти абсолютной, единственной и неизменной. Оно признает относительность и изменчивость государственных форм, их зависимость от исторического развития» [Бердяев, 1927, с. 301]. Связь церкви и государства строится на исторической традиции, не имеет мистического значения и может трансформироваться под влиянием внешних и внутренних факторов.

В идеальном принципе православное христианство принимает любые политические формы. Бердяев утверждал, что с христианством «примирима лишь ограниченная 
государственная власть» [1927, с. 302]. Абсолютизация государственной власти государством не допускается.

Нельзя признать идеальной и онтологически обоснованной и какую-либо модель государственно-церковных отношений (папоцезаризм, цезарепапизм, народопапизм). При этом об идее симфонии властей (государственной и церковной) он не писал, гармонизацию отношений он видел в реализации принципа свободы выбора. Спасение человека, по его мнению, возможно лишь через достижение истинной свободы, истоки которой находятся в иррациональной и трансцендентной бесконечности.

\section{Заключение}

Таким образом, оригинальная концепция свободы, разработанная Н.А. Бердяевым, нашла свое отражение и в его идее христианизации государства. Отождествляя понятия христианского государства и теократии, он полагал невозможность его фактического осуществления. История, по его мнению, знает примеры символически христианских государств, но по сути христианскими не являвшихся, признаками которых выступали вероисповедное господство, клерикализация, иерократическое подчинение, отсутствие свободы вероисповедания. При этом вероисповедным, полагал он, может быть и светское государство, подчиненное даже сатанократической религии. Задачей Церкви, по его мнению, должно быть не стремление к вероисповедному господству, а христианизация общества. Отсутствие свободы вероисповедания, привилегированное положение какой-либо религии приводит лишь к зависимости Церкви от государства и формированию системы государственной церковности.

\section{Список источников} $280-305$.

1. Бердяев Н.А. 1927. Проблема христианского государства. Современные записки, 31 :

2. Бердяев Н.А. 1911. Философия свободы. М., Путь, 280 с.

3. Бердяев Н.А. 1907. Новое религиозное сознание и общественность. СПб., Издание М.В. Пирожкова, 233 с.

4. Бердяев Н.А. 1946. Русская идея (Основные проблемы русской мысли XIX века и начала XX века). Париж, 260 с.

\section{Список литературы}

1. Акопов С.В. 2001. С.Л. Франк как политический мыслитель: автореферат дис. ... кандидата политических наук. СПб, $21 \mathrm{c.}$

2. Алонцева Д.В. 2013. Государственно-правовые взгляды С.Н. Булгакова: автореферат дис. ... кандидата юридических наук. Курск, 28 с.

3. Дендиберя А.А. 2015. Идеи Н.А. Бердяева о государстве и праве. Философия права, 4(71): $28-30$.

4. Ментюкова М.А. 2010. Государственно-правовые воззрения Питирима Александровича Сорокина: автореферат дис. ... кандидата юридических наук. СПб, 29 с.

5. Сазонова Т.Б. 1998. Право и правосознание в учении И.А. Ильина: дис. ... кандидата юридических наук. Благовещенск, 143 с. $180 \mathrm{c}$.

6. Фомина И.Р. 2010. Этика права С.Л. Франка: дис. ... кандидата философских наук. Тула,

7. Черноков А.Э. 2002. Учение С.Л. Франка о государстве и праве: автореферат дис. ... кандидата юридических наук. СПб, 28 с.

8. Яхина А.Р. 2007. Учение П.И. Новгородцева о праве и государстве: автореферат дис. ... кандидата юридических наук. Волгоград, 24 с. 


\section{References}

1. Akopov S.V. 2001. S.L. Frank kak politicheskij myslitel' [S.L. Frank as a political thinker]: avtoreferat dis. ... kandidata poli-ticheskih nauk. $\mathrm{SPb}, 21 \mathrm{p}$.

2. Alonceva D.V. 2013. Gosudarstvenno-pravovye vzglyady S.N. Bulgakova [State-legal views of S.N. Bulgakov]: avtoreferat dis. ... kandidata yuridicheskih nauk. Kursk, 28 p.

3. Dendiberya A.A. 2015. Idei N.A. Berdyaeva o gosudarstve i prave [Ideas of N. A. Berdyaev about the state and law]. Filosofiya prava, 4(71): 28-30.

4. Mentyukova M.A. 2010. Gosudarstvenno-pravovye vozzreniya Pitirima Aleksandrovicha Sorokina [State-legal views of Pitirim Alexandrovich Sorokin]: avtoreferat dis. ... kandidata yuridicheskih nauk. $\mathrm{SPb}, 29 \mathrm{p}$.

5. Sazonova T.B. 1998. Pravo i pravosoznanie v uchenii I.A. Il'ina [Law and legal awareness in the teaching of I. A. Ilyin]: dis. ... kandidata yuridicheskih nauk. Blagoveshchensk, $143 \mathrm{p}$.

6. Fomina I.R. 2010. Etika prava S.L. Franka [Ethics of law S. L. Frank]: dis. ... kandidata filosofskih nauk. Tula, $180 \mathrm{p}$.

7. CHernokov A.E. 2002. Uchenie S.L. Franka o gosudarstve i prave [Frank's teaching on the state and law]: avtoreferat dis. ... kandidata yuridicheskih nauk. SPb, $28 \mathrm{p}$.

8. YAhina A.R. 2007. Uchenie P.I. Novgorodceva o prave i gosudarstve [The teaching of P.I. Novgorodtsev about law and the state]: avtoreferat dis. ... kandidata yuridicheskih nauk. Volgograd, $24 \mathrm{p}$.

\section{ИНФОРМАЦИЯ ОБ АВТОРЕ}

Сафронов Никита Алексеевич, магистр права, заместитель отдела судебной статистики и правовой информатизации Белгородского областного суда, г. Белгород, Россия

\section{INFORMATION ABOUT THE AUTHOR}

Nikita A. Safronov, master of law, Deputy of the Department of judicial statistics and legal Informatization of the Belgorod regional court, Belgorod, Russia 